\title{
Developing Students' Action Competence for a Sustainable Future: A Review of Educational Research
}

\author{
Shih-Yeh Chen ${ }^{1}(1)$ and Shiang-Yao Liu ${ }^{2, *(1)}$ \\ 1 Taichung Municipal Dali High School, Taichung 41260, Taiwan; 80345001s@gmail.com \\ 2 Graduate Institute of Science Education, National Taiwan Normal University, Taipei 11677, Taiwan \\ * Correspondence: liusy@ntnu.edu.tw
}

Received: 16 January 2020; Accepted: 4 February 2020; Published: 13 February 2020

\begin{abstract}
The goal of education for sustainable development is to develop future citizens who can make informed decision and take responsible action to solve the problem. The concept of action competence proposed by Jensen and Schnack in 1997, which emerges as a critical thought from traditional environmental education, gradually attracts the attention with the maturing on the idea of sustainability. This research aims to systematically analyse the peer-reviewed studies published between 1997 and 2017 that embraced the concept of action competence as the instructional approach. After coding 170 articles from two quality databases, some patterns emerge from the year of publication in the resulting 34 empirical studies. Findings on the research design, pathway of intervention, instructional setting, and learning outcome increase our understanding of action competence applied in the authentic context. There is a sharp increase on the inter-disciplinary topic of sustainable development. It reflects the influence of the intergovernmental agreement and the resilience of action competence from environmental education to education for sustainable development. Reviewed studies indicate that action-oriented and transformative pedagogy cultivate students to be active participants, empower their capability of deliberating the causes and effects, and construct their visions for finding strategies toward the problems.
\end{abstract}

Keywords: action competence; empowerment; environmental education; sustainable development; review

\section{Introduction}

The goal of education is to shape human behaviour with all external and internal factors come from the social and value system [1,2]. In environmental education (EE), behaviour change has been the emphasis in school curriculum and other informal as well as nonformal environmental programs $[3,4]$. However, behaviour change, as the aim of moralistic pedagogical approach, has been proven ineffective mostly because students cannot take action based on their decisions [5-10]. In 1972, as EE was formally advocated from the international conference held in Stockholm [11], solving the environmental problems individually and collectively became the goal and main issue in this area $[12,13]$. In the Tbilisi declaration, EE put emphasis on the development of knowledge, values, attitudes, commitment, and skills in response to the goal that "to create new patterns of behaviour of individuals, groups and society as a whole towards the environment" [12] (p. 26). Therefore, EE research is aimed to raise people's awareness, knowledge, attitude, and value for improving pro-environmental behaviour, which is unique from other educational research areas $[1,3,4,14]$. The evaluation reports of EE programs tended to be positive in academic schooling and behaviour modification $[3,4,15]$. However, these positive outcomes could not guarantee learners to be conscious of the emerging or existing problems and to act for a sustainable future [8,10]. In 1987, a new focus of EE, sustainability, was proposed [16], which stressed the complex relationships among environmental, social, and economic aspects of the 
problem that humans are dealing with. Recently, with the proposal of education for sustainable development goals (SDGs) [17], the need to act for achieving the goals for a sustainable future is imperative in all educational systems. For educating toward the goals, learner-centred, action-oriented, and transformative approaches would be the way to empower students to take action in their local and daily lives [17-19].

Action competence approach for EE, proposed by Jensen and Schnack in 1997 [20], is a breakthrough on differentiating action from behaviour $[10,21]$ and stressing critical thinking for transformative learning $[9,22]$ with teachers as facilitators of students' learning $[8,23,24]$. From their work formally initiated in Denmark in 1993, after planning meetings, case studies, and teacher training, the concept of action competence as educational approach was enacted at the Research Center for Environmental and Health Education [21]. This action competence proposal reflects a critical thought of overemphasizing knowledge about the severity of environmental problems, intended behaviour changes, academic achievements on schooling, and inauthentic situations in teaching $[8,20]$. In traditional EE, emphasis is often put on knowledge, attitude, and behaviour change at the individual level [16] that fails to consider actions taken in the social and political contexts [24]. On the contrary, action competence promotes a collective avenue, which would lead student learning to comprehending the action and change process in the real world [24,25]. Opportunities of planning and taking action in authentic contexts benefit their social skills to solve the problem and further bring about change as citizens. Through the learning process, students could be equipped as action competent individuals with critical and democratic perspectives $[10,22]$. Consequently, students' consciousness of the problem and the causes is based not only on their opinions and motivation, but also on vision and commitment.

Twenty more years after the publication by Jensen and Schnack, the action competence approach has been adopted in the studies of EE and other educational fields. The present study aims to understand the impact that such an instructional approach had on these research fields by systematically analysing the peer-reviewed, empirical studies.

\section{Methodology}

\subsection{Inclusion Criteria}

In the present study, SCOUPUS and Web of Science databases were selected to maintain the quality of our reviewed studies. The journal articles, citing the article of Jensen and Schnack [20], publishing from 1997 to 2017 were searched. To ensure the quality of this review effort, the selected articles must meet the following criteria: (1) published in peer-reviewed journals, (2) first-hand empirical studies, and (3) using action competence as the foundation for instructions in the educational context. Pertaining to the third criteria, first, the studies had to cite the publication of Jensen and Schnack [20] as the theoretical foundation of their research design. Second, the concept of action competence had to be delivered in the instructional content. In the initial search, a total of 324 studies from the two databases were found, of which 92 were duplicates. According to the PRISMA 2009 guideline [26], articles classified as conference paper, book chapter, editorial, and review were eliminated. Then, 170 articles fit the eligibility of this research endeavour and further evaluated twice to ensure they met the selection criteria of adopting action competence in their design of research. Two papers were not available. For not specific ones, participants in three studies were not clear while four papers did not elaborate the details of their instruction. Most of the papers belonged to the survey and the development of the model, theory, or tool. Although some of the papers were empirical studies, the research design did not target at the development of action competence. Finally, the selection of the systematic literature review included 34 articles in our data analysis. The inter-rater reliability was conducted by choosing one fifth of the articles for both authors to analyse individually. With constant comparisons, all discrepancies were discussed until agreements were achieved. Figure 1 showed the literature search and review process. 


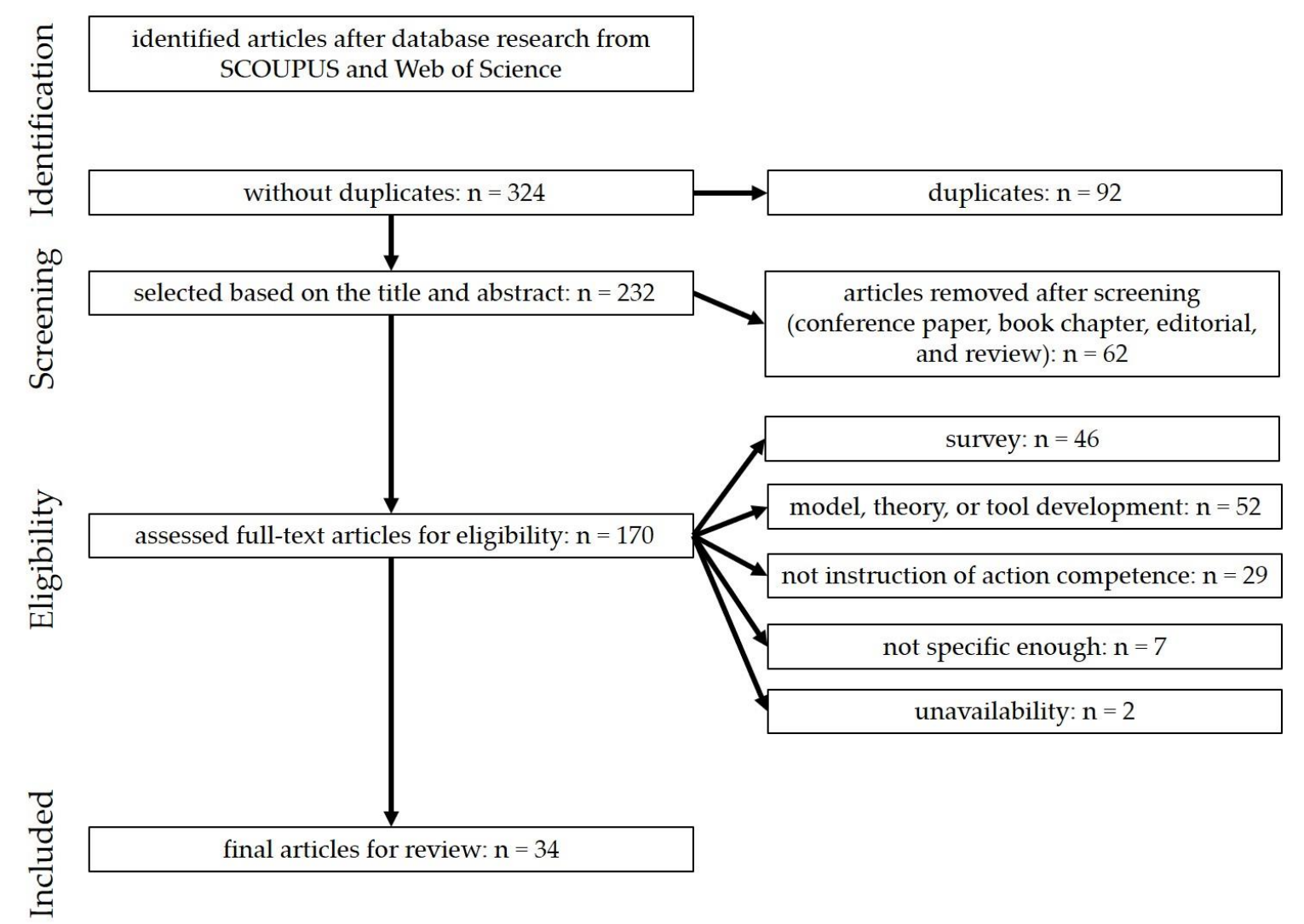

Figure 1. The diagram of the literature search and review process.

\subsection{Analysis Framework}

At the beginning, we categorized articles by the characteristics of the studies, including the field of the journal, year of publication, and geographic distribution of the studies conducted, to have an overview of these articles. Then, the research design, pathway of intervention, instructional setting, and learning outcome were coded by authors independently as described above. The pathway of intervention comprised the subject matter domain and teaching topic. The instructional setting consisted of the educational level, duration of instruction, and learning context. Further, possible factors were inferred from political, social, and environmental aspects to explain the results we obtained [3].

\section{Results and Discussion}

This section provides a concise and precise description of the experimental results, interpretations, as well as the experimental conclusions that can be drawn.

\subsection{Characteristics of the Studies}

All of the studies analysed were mainly distributed in the field of EE, health education, science education, and curriculum studies (see Supplementary Materials Table S1). According to the year of publication among these studies in Figure 2, there were substantial papers reported after 2010 in contrast to those published between 1997 and 2009. Regarding the geographic distribution of research conducted areas, America was the continent with the highest percentage of studies (35\%, only one study in South America), followed by Europe (28\%), Oceania (23\%), Asia (10\%), and Africa (5\%). By adopting 2010 as the demarcation (see Table 1), the dominant studies were in Europe before 2010. After that, studies in America have made significant progress in this area as well as Oceania. Especially, in recent years, there were studies commenced in Asia (e.g., $[23,27])$. 


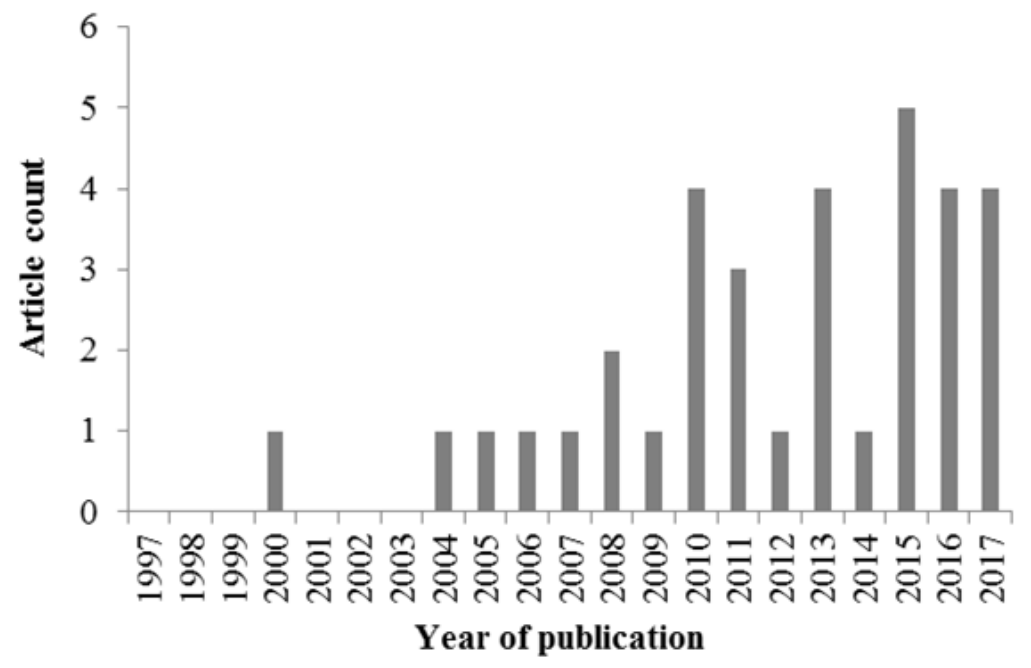

Figure 2. Number of publications in each year.

Table 1. Geographic distribution of the studies published before and after 2010.

\begin{tabular}{ccc}
\hline \multirow{2}{*}{ Geographic Distribution } & 1997-2009 & 2010-2017 $^{\text {2010 }}$ \\
\cline { 2 - 3 } & Number of Articles $^{\text {a }}$ & Number of Articles $^{\text {a }}$ \\
\hline Europe & 4 & 7 \\
America & 2 & 12 \\
Oceania & 2 & 7 \\
Africa & 1 & 1 \\
Asia & 0 & 4 \\
\hline
\end{tabular}

a The sum of the articles is greater than 34 as some studies were conducted in more than one continent.

The number of the published articles increased abruptly with $76 \%$ of the studies published between 2010 and 2017. Broadly speaking, the abundance of the studies conducted in America that might result from the remarkable progress and research of EE in the United States [3,28]. Europe, the birthplace of action competence approach in EE, still developed and extended the concept in educational research [10]. Echoed with the review on action in formal learning context [29], studies carried out in North America and Europe by researchers were substantial in recent years. Some studies were transnational programs initiated from Denmark [30-32] and from Canada [19,33]. In addition to collaborating in research with other nations, researchers could further comprehend the influence of action competence in these programs on the participants shaped by various cultural contexts, and detect the process and mechanism of the programs in these empirical studies [34].

\subsection{Research Design}

With regard to the design of research, qualitative, quantitative, and mixed methods served as the criteria for categorization [15,35]. Table 2 shows the categorizations of research design and corresponding numbers of article before and after 2010. Most of the articles were qualitative studies (56\%), and $23 \%$ were quantitative studies as well as $21 \%$ mixed methods studies. Before 2010 , only $13 \%$ of the studies were mixed methods and the remaining were qualitative. After 2010, 46\% of the studies belonged to qualitative methods while $31 \%$ and $23 \%$ were quantitative and mixed methods respectively.

The dominance of the qualitative studies revealed that the researchers put emphasis on the process of developing and shaping students' competence, and stressed the interpretation of learning courses from the epistemic view [36]. The assumption of the qualitative evaluation was based on the interactive process of the researchers and those being researched in order to construct the understanding and meaning [32]. It also stressed the importance of learning conditions [10] for developing and qualifying action competence and focused on the learning process instead of overemphasizing the outcome of the 
project [36]. Action competence is not only characterized as holistic philosophy rooted in EE [10,16], but also corresponded to the emancipatory knowledge claim toward changing the status quo [35]. Therefore, the qualitative methods were adopted as primary research method at the early stage of this research trend.

Table 2. Categorizations of research design.

\begin{tabular}{cccc}
\hline Research Design & No. of Articles & No. of Articles (before 2010) & No. of Articles (after 2010) \\
\hline Qualitative & 19 & 7 & 12 \\
Quantitative & 8 & 0 & 8 \\
Mixed methods & 7 & 1 & 6 \\
\hline
\end{tabular}

Research pertaining to quantitative methods emerged after 2010. For example, Gottlieb et al. [23] compared the learning outcomes between the experimental and control group by implementing the learning subject of ecological footprint. The program allowed students to identify the causes and consequences of the problem, search action possibilities, and change strategies in solving a real problem in their school community. Through awaking students' consciousness of enacting an action plan, the program actually increased the perception of behavioural control and personal norms, and behavioural intentions. As mentioned in Gottlieb et al.'s article "school does not become 'green' by conserving energy, collecting batteries, or sorting waste" (p. 859), cultivating students to plan and make changes toward sustainability in the school and neighbourhood community should be the primary goal of such educational projects. However, some situational factors would influence their performances. To explore how students deliberated and acted on the events during the intervention could advance our understandings about how the learning conditions affect them. While it was difficult to make quantitative evaluation on participation, reflection, or critical thinking, research may be inclined to adopt the interpretative and socio-critical perspectives to know the effectiveness of the program. Notwithstanding, quantitative methods had its advantages in figuring out the variables affecting the outcomes through comparing with the control group. Adopting or combining different methods in the research design could neutralize or eliminate the biases in each method, which benefited the comprehension of the intervention.

\subsection{Pathway of Intervention}

\subsubsection{Subject Matter Domain}

Initially, EE was incorporated into the formal education system accompanied by natural studies and life science (e.g., ecology), which played the role of describing environmental problems [8,23,37]. However, documents from the Tbilisi Declaration [12] and Agenda 21 [38] have established the multi-disciplinary nature of EE. Therefore, EE should not be limited to some specific subject, but be implemented through various subjects [8].

Table 3 demonstrates the distribution of subject matter domains in this analysis. From the number of articles, $22 \%$ of the studies were through science subject (e.g., [39]). Other non-science subjects, such as art [18,40], social study [41], geography [23], and education [42], were also included $(14 \%)$. The dominance was the inter-disciplinary project (64\%). Two studies took place in more than one domain and were counted more than once [40,41]. Given the publication year of 2010 as a cut-off point, only one study [42] was on non-science subjects before 2010. After 2010, studies from various subject matter domains including art, social study, and geography were revealed.

The dominance in inter-disciplinary project echoed to the statements of Gottlieb et al. [23]: "action competence is developed best if students obtain insight into environmental problems by inter-disciplinary inquiry through working on projects" (p. 846). In aligned with this understanding, the IVAC model (investigations, visions, actions, and changes) was adopted and applied in four studies [8,30-32] originated from the areas of the environmental and health education in Danmark. 
The model helped students "see environmental problems as the structural and inter-disciplinary problems" [8] (pp. 407-408). In one case, students attempted to make their community better by collaborating with their teachers and community stakeholders. With the aim of improving the richness and liveness of the community, they realized the goals of getting the circus back, establishing a play area, and raising money for charity. Through students' participation and action in the context of interdisciplinarity, students were empowered by working with authentic problems. The saying that "the complex of 'causes' is not clarified, and the action level is never reached" (p. 407), advocates the holistic outlook of studying environmental problems by inter-disciplinary approach [16]. In recent years, studies on different subjects revealed the trend that developing action competence for changing the world seemed to be adequate for teachers in different disciplines to enact in their instructions. Prompting students to act toward the local and global challenges from various subject domains would encourage problem solving from different point of views.

Table 3. Subject matter through intervention.

\begin{tabular}{cccc}
\hline Subject & No. of Articles & No. of Articles (before 2010) & No. of Articles (after 2010) \\
\hline Inter-disciplinary & 23 & 5 & 18 \\
project & 8 & 2 & 6 \\
Science & 2 & 0 & 2 \\
Art & 1 & 0 & 1 \\
Social study & 1 & 0 & 1 \\
Geography & 1 & 1 & 0 \\
Education & 1 & 5 & 0 \\
\hline
\end{tabular}

\subsubsection{Teaching Topic}

Regarding the implementation of courses or curricula, each study incorporated one or several topics. Table 4 presents a variety of teaching topics from the review. Half of the studies (53\%) adopted the topic of sustainability or sustainable development (SD). Before 2010, only $13 \%$ of the studies were related to sustainability or SD [43]. However, studies after 2010 increased to $65 \%$ that embraced SD related topics. Some topics (e.g., environmental justice in [19] and [33]) emerged after 2010. Other topics such as health promotion (e.g., [8] and [30]) and environmental health (e.g., [39]) have also been investigated. For instance, Bohnet et al. [40] carried out the plan to prevent water pollution in the basin of Australia. Students from seven primary schools took part in this project by visioning the future of their community. By collaborating with community members who provide their perspectives, students deliberated and reflected the current state and future of the community as well as constructed the model of their living space to make a change. With adequate guidance to vision the future for learning sustainability, students would not only take responsibility toward themselves and their school but "transcend school boundaries" (p. 195) to the living and non-living elements of our planet.

Table 4. Listing of teaching topics.

\begin{tabular}{cccc}
\hline Topic & Number of Articles & No. of Articles (before 2010) & No. of Articles (after 2010) \\
\hline Sustainability or SD & 18 & 1 & 17 \\
Environmental justice & 2 & 0 & 2 \\
Watershed management & 1 & 0 & 1 \\
Wildfire risk reduction & 1 & 0 & 1 \\
Natural resource conservation & 1 & 0 & 1 \\
Health promotion & 4 & 3 & 1 \\
Environmental health & 2 & 1 & 1 \\
Social capital in urban community & 2 & 1 & 1 \\
Environmental action & 2 & 1 & 1 \\
Global warming & 1 & 1 & 0 \\
Health and cycling & 1 & 1 & 0 \\
Garbage management & 1 & 1 & 0 \\
\hline
\end{tabular}


Teaching topics were affluent as in the review of Varela-Losada et al. [29], whereas some trend could be observed in our review. Ever since in 1975, there have been criticisms and comments concerning the lack of the direction in EE [1]. After World Conservation Strategy first proposed the word "sustainability" in 1980 [44], the World Commission on Environment and Development further defined and promoted the concept of sustainable development in Brundtland Report [45]. The goal of EE was redirected towards education for sustainable development (ESD) [16] while to some extent the lines between EE and ESD were blurred [28]. In the past decade, the United Nations (UN) proclaimed the United Nations Decade of Education for Sustainable Development (UNDESD) in 2005-2014, and designated United Nations Educational, Scientific and Cultural Organization (UNESCO) as the lead agency to integrate resources and promote the Decade [46]. In 25 September 2015, the UN adopted 2030 Agenda for Sustainable Development to extend the follow-up of the UNDESD with corresponding 17 SDGs [17]. In addition, Mogensen and Schnack [10] manifested the action competence as an educational ideal from EE to ESD. By emphasizing knowledge sharing and collaboration through connecting to the German concept of "Bildung," thereby, action competence became the promising approach to achieve the aim of ESD. With the two factors stated above, the reasons imbedded in the abrupt publications related to SD after 2010 are apparent. The trend of adopting SD as teaching topic would last for years while more and more "wicked problems" [47] gradually threatened our living world.

\subsection{Instructional setting}

\subsubsection{Educational Level}

The categories of educational level include pre-school (year 4-6), elementary school (year 7-12), middle school (year 13-15), high school (year 16-18), and higher education (undergraduate/graduate). Additionally, research on teachers is also considered because teachers often acted as designers of the environmental program and facilitators of students' learning $[29,42]$. Pre-service and in-service teachers were included in our analysis of the educational level. Figure 3 shows the range of the educational level presented in each study. Some studies were conducted with participants of more than one educational level. One example in the study of Simovska and Jensen [32] aimed to foster students to make a difference on the topic of alcohol use. Students of four different countries discussed about the causes and effects of alcohol on the e-forum. Teachers created a learning environment for genuine participation of students where they acted as facilitators and supporters in developing action competence for students. In the later phase, students along with their teachers attended the WHO conference and presented their voices about alcohol consumption and the related problems. Students had opportunities to interact with experts and delegates from different countries to broaden their views concerning the issue. In this case, teachers empowered students to be active learners who are responsible for the decision of the action.

Nearly three-fourths of studies target elementary, middle, and high school students. Regardless of the publication year before or after 2010, the variation on the proportion of the K-12 students was not obvious. Studies concerning to the pre-school students were rare. While the situation of the global environment called for the education that would inspire action as early as possible [48], early childhood education on developing competences toward changing the world was demanding. For the sustainable environment, children should co-decide their future through an action-oriented and participatory approach to impact their own community. We also found that a few studies were initiated toward in-service teachers and community stakeholders after 2010. Teachers, and EE curriculum designers and implementers have a great deal of influence on developing students' action competence in formal education. While the development of action competence relied on the collaboration of not only students and teachers but also other stakeholders in the local community, such as the residents, private industry, council, and government office [25]. Community stakeholders also provide technique or social support on fostering student competence [25,36,39]. In some cases [49-52], a variety of the community stakeholders along with the school members promoted the change in the locality. While the 
composition of community stakeholders is complex, analysing their role in the action is beyond the scope of this review. Consequently, comprehending the function and role of the in-service teachers and community stakeholders in supporting the environmental projects would be a promising model to foster dialogues between the school and local community $[8,24,51]$.

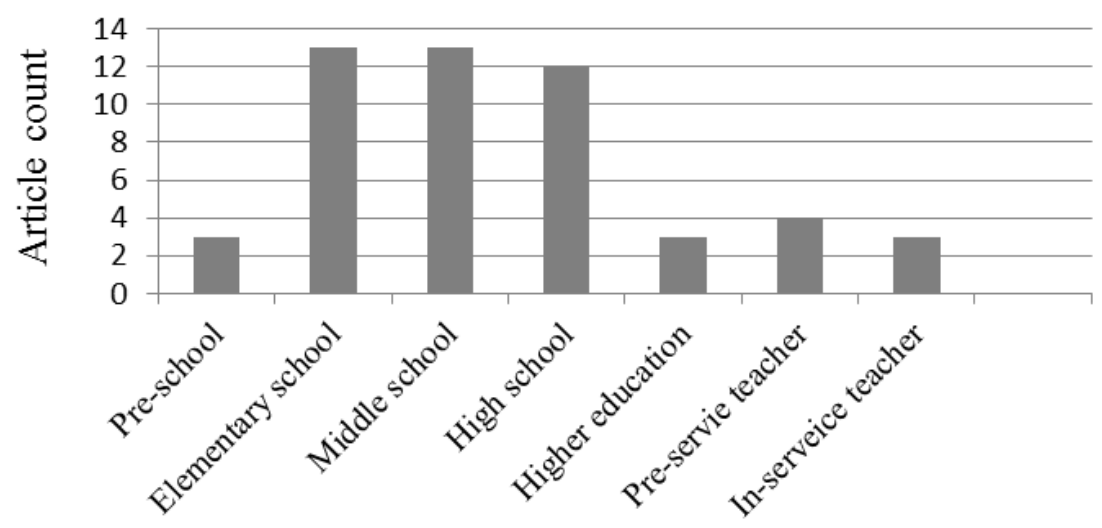

Educational level

Figure 3. Range of the educational levels.

\subsubsection{Duration of Instruction}

Table 5 depicts the length of the instructions the studies reported. Most of the studies were located at the intervals of one week to one semester $(29 \%)$ and one semester to one school year $(26 \%)$. Some instructional programs lasted over one school year (15\%); however, some studies $(18 \%)$ did not report the duration of instruction. The ratio of the studies with duration more than one semester over those less than one semester before 2010 was 0.4 , and the ratio for those after 2010 became 1.33 . This shows that researchers increasingly realize that it takes longer to cultivate action competence of learners.

Table 5. Duration of instruction in the analysis.

\begin{tabular}{cc}
\hline Duration of Instruction & Number of Articles \\
\hline Less than one day & 2 \\
One day to one week & 2 \\
One week to one semester & 10 \\
One semester to one school year & 9 \\
More than one school year & 5 \\
N.A. & 6 \\
\hline
\end{tabular}

As illustrated above, these studies were mainly inter-disciplinary projects, and the collaboration between the school teachers, community members, private industry, and government agencies were common [25,32,39,52]. Wake and Eames [36] demonstrated an exemplar on collaborating with stakeholders within the community for a four-year program. Students worked together on a project of designing and constructing an eco-classroom using environmentally friendly materials and techniques. In addition to the students and their teachers, the school principal, parents, project manager, builders, architecture firm, and foundation were involved. In this process, students not only experienced making bricks by themselves but also made decisions toward the changes during the construction by which their commitment to and ownership of the project were valued. The program provided "authentic and relevant sustainability learning experiences for children" (p. 318) in which students were empowered with the ability to enact and implement EDS action. However, it is time-consuming for students to integrate resources, make plans, and complete actions, which caused one of the barriers 
in school system that was also mentioned in other studies (e.g., [53]). Chawla and Cushing [25] and Rickinson [15] have suggested that an extended duration of time would make environmental projects more effective. From the review of literature, educators have been aware of the need of more time for the development of action skills [16].

\subsubsection{Learning Context}

According to the categorization of learning context [54], formal, informal, and non-formal education were sorted out. The judgement of the learning context was based on the research context or intervention program described by the researchers [55]. The majority of the studies were related to the formal learning context $(76 \%)$, followed by informal $(65 \%)$ and non-formal $(12 \%)$ learning contexts, while some studies combined the formal and informal learning context (35\%). After 2010, the non-formal learning context started to appear in the design of research. Only one study implemented in the non-formal learning context was conducted recently [52]. They adopted information and communication technology tools to assist community members to learn sustainability in non-formal context. These community stakeholders, including teachers, environmental authorities, and tourism providers, explored sustainability issues in the interactive web-site. Most of the participants demonstrated positive learning outcomes and obtained new perspectives toward the issues. In addition, they also carried out actions toward the community issue while individual actions dominated. The results suggested that non-formal education in the local community providing a new path for cultivating participants' transformative understanding of local issues and competence of action.

The large amount of the formal learning context reflected the initiative of action competence by Jensen and Schnack [20], which was based on the school context. However, with the limited resources at school for participating in the authentic problems, students needed supports from or learning experiences in the agencies of local community [24]. Therefore, instructions in the informal learning context were imperative in these studies. A combination of two contexts was also prominent, such as eco-classroom architectural project [36], collaborative web-based forum for indirectly acting on the international conference [32], and the issue of alcohol consumption [8]. For the EE/ESD of the local community, non-formal learning context was the essential part for the goal of life-long learning by building partnership and influencing action of the community members. Since the non-formal learning context was an inseparable part of the whole education system, the investigation and evaluation of action competence in the non-formal learning context still needed more efforts.

\subsection{Learning Outcome}

While action competence was featured by the holistic philosophy [10], the judgement of the learning outcome was based on the whole results of the article. According to the explanations interpreted by the researchers, if the results are aligned with their research assumptions, the outcome of the study is coded as positive [3,4], otherwise negative.

A total of $94 \%$ studies reported positive outcomes, which meant the majority of the studies exhibited that the participants developed their action competence in these educational proposals. In the study of Lynch et al. [39], primary school students and teachers collaborated with researchers and scientists from university to monitor the changes of the local coast. With the involvement of various stakeholders in the local area, the council supported the plan of coastal management and the catchment authority offered data for students to do investigation. After the field trip, students chose two locations, the river mouth and dune area, to put camera for monitoring the area. Local residents also provided old photos to extend "the project back in time" (p. 714). Data collected from the camera were transmitted to the online database, and students could download the photos to analyse the differences under the guidance of their science teachers. The project outcomes were then presented in the family science night that involved the participations of parents, schools, and project implementers in local community. After one-year implementation, the course participants expanded from one class 
to all of the five and six graders in order to equip students with adequate competence on acting toward the community affairs.

Only two $(6 \%)$ of the studies showed negative outcomes, one is in science and the other in non-science domain [42,43]. These two studies were published before 2010. Barrett and Sutter [43] conducted a youth forum for high school students in the museum. The course, based on action-oriented approach, targeted on the topic of sustainable development and provided opportunities for students to deal with the complex issues of sustainability. Students had difficulty to engage in the course, which was revealed from the distraction of the students during the instruction. While the museum was accustomed to pre-school and primary school students, their course was not for secondary-level students. From the perspective of evaluation, the teachers thought that the course was beyond the formal science curriculum. From this study, it was recognized that stakeholders responsible for developing student action competence play key roles in influencing the success of the EE/ESD project.

Previous reviews also found that most of the studies had positive outcomes in EE $[3,4,56]$. Those learning outcomes were measured immediately after the course completed. Only $9 \%$ of the studies included delayed measurements on the environmental action and intention for future action $[19,52,57]$. However, the delayed measurements suggested negative outcomes mostly as they stated the impact of the educational proposals could not sustain students' actions or meet researchers' expectation. Take Riemer et al.'s study [19] as an example, they recruited students from six countries to attend the workshop series for leading environmental change. The workshop focused on the environmental justice and building action competence. They collected the data in three, six, and twelve months by interview as well as questionnaire in the beginning of the workshop, and on-line survey at the end. Students indicated cognitive and affective connection with the environmental issues. However, after one year, their environmental action perished back to the state before they joined the workshop. This result revealed that "personal transformations are not sufficient in creating long-term change" (p. 185). If educators were dedicated to engaging students in taking life-long action, continuing social support from relevant projects or existing institutions would be necessary to keep the fire burning.

The critical element in most studies was the action-oriented experiences (e.g., $[18,19,29,31])$ that empower students to make changes and solve authentic problems in a democratic society $[1,4,9,16,21,25]$. Instructional proposals adopted the action competence approach made students not only aware of the phenomenon but also conscious of the problem that needs to be solved. In addition, they could be aimed to develop the ownership in individual sense and the empowerment in collective sense $[1,10,24,25]$. While the EE studies targeted at measurements of action competence were still rare [3], further studies were expected to present the outcomes of the influential or effective action for the environment. In alignment with the approach of ESD [17], taking informed decision and responsible action for the environment would empower the competences of the learners. This would promote students to treat the environmental and societal issues from various perspectives and engage them in socio-political processes consistent with the democratic education paradigm [17,58,59]. Accordingly, recognizing how the educational proposals empowered students with action competence would be beneficial for the realization of ESD.

Delayed measurements focused on the evaluation of action to address the long-term impact of the educational proposals. As the outcomes here were not satisfied, the continued reinforcement after the intervention [52] might be the solution to alleviate this situation. The evaluation needed to look beyond the immediate outcomes and should put emphasis on life-long practices.

Concerning the learning outcomes in this review, only two studies were negative [42,43]. In order to understand the possible factors influencing the learning outcome, it was imperative to inspect the learning conditions in contrast to the two studies. First, both of them used a qualitative design, which allowed researchers to examine the learning process and further to find the causes inherent to the outcomes. Second, these two studies were conducted in certain subject matter domain, one in science and the other in education. In line with the nature of EE/ESD [12,17], developing action 
competence in inter-disciplinary context should be a promising choice of researchers. In addition, the chosen topics of the two studies were sustainability and environmental action. This reflected the difficulty and complexity in understanding sustainability [16] and implementing action [5]. Third, participants enrolled in these two studies were high school students and pre-service teachers, respectively. Studies conducted in the other educational levels, such as pre-school, elementary school, middle school, and in-service teachers, all show positive outcomes. Among them, studies implemented in elementary and middle schools accounting for half in this review. Therefore, echoing the findings of Leiserowitz, Kates, and Parris [60] and Bascopé et al. [48], these positive outcomes revealed the possibility of promoting students to have positive attitude, value, as well as action toward environment at an early stage in EE/ESD. More instructional efforts might be needed for upper secondary and higher education stage. In fact, it was found that all of the studies in this review demonstrated positive outcomes when their instructional time exceeded one semester. This trend of increasing instructional time became apparent in the studies after 2010. The final point regarding these two negative studies is that one was in formal education and the other one was informal. This review indicates that research combining formal and informal learning contexts, as well as involving non-formal context revealed positive outcomes.

\section{Conclusions}

The purpose of this review is to provide scholar communities with the current state on the concept of action competence in educational fields. First, the results show that most of the articles were published after 2010, with significant growth of publications in America. Qualitative design is prevailing as action competence stresses the importance of learning condition and focuses on learning process. Second, inter-disciplinary project is dominant, followed by science courses as the kind of subject in recent years. At the same time, teaching topics are largely targeted on sustainable development, which reflect the concern of the international organizations and the realization of action competence to achieve sustainability. Third, children and adolescences are still the focus of the studies, but the researchers in recent studies become more interested in the roles of in-service teachers and community stakeholders. The competence of pre-school students is the target of future research. The instructional time reported in the articles shows a tendency of increasing. Formal and informal learning contexts are massively utilized by researchers, and non-formal learning context is not adopted until 2017. Finally, the learning outcomes are almost positive. The delayed measurements used in evaluating the outcomes are published after 2016, and it is necessary to consider the long-term effect of the instruction to meet the goal of EE/ESD as life-long participation. As the goal of education is action [61], to equip students as well as residents around world with action competence would be the aim of the educators for visioning a sustainable future of our planet. The results showed from the review would provide educators and teachers with the design and details of the curriculum development on action competence in the educational context.

\section{Limitations}

A limitation of this review is the definition between behaviour and action. Some researchers still consider behaviour equalling to action [3,62]. Taking this confusion into account, we discard those who do not cite the article of Jensen and Schnack [20] as the starting point of EE/ESD. Therefore, some studies might have been excluded from this review, which could limit our interpretations about differences between behaviour change and action competence.

Typically, articles reviewed are constrained by a publication bias [63]. While peer-reviewed journals prefer to publish positive outcomes rather than negative ones [3], the articles selected in this review tend to report significant effects more than non-significant effects as research outcomes. Some negative outcomes are ignored by researchers without further exploration.

Supplementary Materials: The following are available online at http://www.mdpi.com/2071-1050/12/4/1374/s1, Table S1: The fields and selected outcomes of the studies in this analysis. 
Author Contributions: S.-Y.C. and S.-Y.L. contributed to the conceptualization and design of the work. S.-Y.C. drafted the manuscript. S.-Y.L. reviewed and edited the manuscript. All authors have read and agreed to the published version of the manuscript.

Conflicts of Interest: The authors declare no conflict of interest.

\section{References}

1. Hungerford, H.R.; Volk, T.L. Changing learner behavior through environmental education. J. Environ. Educ. 1990, 21, 8-21. [CrossRef]

2. Kollmuss, A.; Agyeman, J. Mind the Gap: Why do people act environmentally and what are the barriers to pro-environmental behavior? Environ. Educ. Res. 2002, 8, 239-260. [CrossRef]

3. Ardoin, N.M.; Bowers, A.W.; Roth, N.W.; Holthuis, N. Environmental education and K-12 student outcomes: A review and analysis of research. J. Environ. Educ. 2018, 49, 1-17. [CrossRef]

4. Stern, M.J.; Powell, R.B.; Hill, D. Environmental education program evaluation in the new millennium: What do we measure and what have we learned? Environ. Educ. Res. 2014, 20, 581-611. [CrossRef]

5. Birdsall, S. Empowering students to act: Learning about, through and from the nature of action. Aust. J. Environ. Educ. 2010, 26, 65-84. [CrossRef]

6. Breiting, S.; Mogensen, F. Action competence and environmental education. Camb. J. Educ. 1999, 29, 349-353. [CrossRef]

7. Jensen, B.B. A case of two paradigms within health education. Health Educ. Res. 1997, 12, 419-428. [CrossRef]

8. Jensen, B.B. Environmental and health education viewed from an action-oriented perspective: A case from Denmark. J. Curric. Stud. 2004, 36, 405-425. [CrossRef]

9. Mogensen, F. Critical thinking: A central element in developing action competence in health and environmental education. Health Educ. Res. 1997, 12, 429-436. [CrossRef]

10. Mogensen, F.; Schnack, K. The action competence approach and the 'new' discourses of education for sustainable development, competence and quality criteria. Environ. Educ. Res. 2010, 16, 59-74. [CrossRef]

11. UN. Report of the United Nations Conference on the Human Environment. 1972. Available online: http://www.un-documents.net/aconf48-14r1.pdf (accessed on 3 May 2019).

12. Intergovernmental Conference on Environmental Education (ICEE). The Tbilisi Declaration. 1977. Available online: https://unesdoc.unesco.org/ark:/48223/pf0000032763 (accessed on 31 January 2020).

13. United Nations Educational, Scientific and Cultural Organization (UNESCO). The Belgrade Charter. 1975. Available online: http://unesdoc.unesco.org/images/0001/000177/017772eb.pdf (accessed on 5 December 2018).

14. Niedermeyer, F.C. A checklist for reviewing environmental education programs. J. Environ. Educ. 1992, 23, 46-50. [CrossRef]

15. Rickinson, M. Learners and learning in environmental education: A critical review of the evidence. Environ. Educ. Res. 2001, 7, 207-320. [CrossRef]

16. Tilbury, D. Environmental Education for Sustainability: Defining the new focus of environmental education in the 1990s. Environ. Educ. Res. 1995, 1, 195-212. [CrossRef]

17. UNESCO. Education for Sustainable Development Goals. 2017. Available online: http://unesdoc.unesco.org/ images/0024/002474/247444e.pdf (accessed on 27 November 2019).

18. Jónsdóttir, Á. Teaching and learning for sustainability: An Icelandic practice-based research. Int. J. Educ. Through Art 2015, 11, 391-406. [CrossRef]

19. Riemer, M.; Voorhees, C.; Dittmer, L.; Alisat, S.; Alam, N.; Sayal, R.; Bidisha, S.H.; De Souza, A.; Lynes, J.; Metternich, A.; et al. The youth leading environmental change project: A mixed-method longitudinal study across six countries. Ecopsychology 2016, 8, 174-187. [CrossRef]

20. Jensen, B.B.; Schnack, K. The action competence approach in environmental education. Environ. Educ. Res. 1997, 3, 163-178, reprinted in Environ. Educ. Res. 2006, 12, 471-486. [CrossRef]

21. Fontes, P.J. Action competence as an integrating objective for environmental education. Can. J. Environ. Educ. 2004, 9, 148-162.

22. Piasentin, F.B.; Roberts, L. What elements in a sustainability course contribute to paradigm change and action competence? A study at Lincoln University, New Zealand. Environ. Educ. Res. 2018, 24, 694-715. [CrossRef] 
23. Gottlieb, D.; Vigoda-Gadot, E.; Haim, A. Encouraging ecological behaviors among students by using the ecological footprint as an educational tool: A quasi-experimental design in a public high school in the city of Haifa. Environ. Educ. Res. 2013, 19, 844-863. [CrossRef]

24. Uzzell, D. Education for environmental action in the community: New roles and relationships. Camb. J. Educ. 1999, 29, 397-413. [CrossRef]

25. Chawla, L.; Cushing, D.F. Education for strategic environmental behavior. Environ. Educ. Res. 2007, 13, 437-452. [CrossRef]

26. Moher, D.; Liberati, A.; Tetzlaff, J.; Altman, D.G.; The PRISMA Group. Preferred Reporting Items for Systematic Reviews and Meta-Analyses: The PRISMA Statement. PLoS Med. 2009, 6, e1000097. [CrossRef] [PubMed]

27. Tal, T.; Abramovitch, A. Activity and action: Bridging environmental sciences and environmental education. Res. Sci. Educ. 2012, 43, 1665-1687. [CrossRef]

28. Hungerford, H.R. Epilogue. J. Environ. Educ. 2010, 41, 68-69. [CrossRef]

29. Varela-Losada, M.; Vega-Marcote, P.; Pérez-Rodríguez, U.; Álvarez-Lires, M. Going to action? A literature review on educational proposals in formal environmental education. Environ. Educ. Res. 2016, 22, 390-421. [CrossRef]

30. Carlsson, M.; Simovska, V. Exploring learning outcomes of school-based health promotion-A multiple case study. Health Educ. Res. 2012, 27, 437-447. [CrossRef]

31. Simovska, V. The changing meanings of participation in school-based health education and health promotion: The participants' voices. Health Educ. Res. 2007, 22, 864-878. [CrossRef]

32. Simovska, V.; Jensen, B.B. On-line learning environments and participatory health education: Teachers' reflections. J. Curric. Stud. 2008, 40, 651-669. [CrossRef]

33. Sayal, R.; Bidisha, S.H.; Lynes, J.; Riemer, M.; Jasani, J.; Monteiro, E.; Hey, B.; De Souza, A.; Wicks, S.; Eady, A. Fostering systems thinking for youth leading environmental change: A multinational exploration. Ecopsychology 2016, 8, 188-201. [CrossRef]

34. Dittmer, L.; Mugagga, F.; Metternich, A.; Schweizer-Ries, P.; Asiimwe, G.; Riemer, M. We can keep the fire burning": Building action competence through environmental justice education in Uganda and Germany. Local Environ. 2018, 23, 144-157. [CrossRef]

35. Creswell, J.W. Research Design: Qualitative, Quantitative, and Mixed Methods Approaches; Sage Publications: Thousand Oaks, CA, USA, 2003.

36. Wake, S.J.; Eames, C. Developing an "ecology of learning" within a school sustainability co-design project with children in New Zealand. Local Environ. 2013, 18, 305-322. [CrossRef]

37. Dillon, J.; Scott, W. Perspectives on environmental education-related research in science education. Int. J. Sci. Educ. 2002, 24, 1111-1117. [CrossRef]

38. UNESCO. Agenda 21. 1992. Available online: https://sustainabledevelopment.un.org/content/documents/ Agenda21.pdf (accessed on 5 December 2018).

39. Lynch, J.; Eilam, E.; Fluker, M.; Augar, N. Community-based environmental monitoring goes to school: Translations, detours and escapes. Environ. Educ. Res. 2017, 23, 708-721. [CrossRef]

40. Bohnet, I.C.; Gooch, M.; Hickey, R. Young people envision the future of their local area: An explorative study from the wet tropics, Australia. Appl. Environ. Educ. Commun. 2010, 9, 185-197. [CrossRef]

41. Kumler, L.M. Students of action? A comparative investigation of secondary science and social studies students' action repertoires in a land use context. J. Environ. Educ. 2010, 42, 14-29. [CrossRef]

42. Gooch, M.; Rigano, D.; Hickey, R.; Fien, J. How do primary pre-service teachers in a regional Australian university plan for teaching, learning and acting in environmentally responsible ways? Environ. Educ. Res. 2008, 14, 175-186. [CrossRef]

43. Barrett, M.J.; Sutter, G.C. A youth forum on sustainability meets the human factor: Challenging cultural narratives in schools and museums. Can. J. Sci. Math. Technol. Educ. 2006, 6, 9-23. [CrossRef]

44. IUCN/UNEP/WWF. World Conservation Strategy: Living Resources for Sustainable Development. 1980. Available online: https://portals.iucn.org/library/efiles/documents/wcs-004.pdf (accessed on 26 December 2018).

45. UN. Our Common Future: Report of the World Commission on Environment and Development; Oxford University Press: New York, NY, USA, 1987. 
46. Combes, B. The United Nations decade of education for sustainable development (2005-2014): Learning to live together sustainably. Appl. Environ. Educ. Commun. 2005, 4, 215-219. [CrossRef]

47. Dillon, J.; Stevenson, R.B.; Wals, A.E. Introduction to the special section Moving from citizen to civic science to address wicked conservation problems. Conserv. Biol. 2016, 30, 450-455. [CrossRef]

48. Bascopé, M.; Perasso, P.; Reiss, K. Systematic review of education for sustainable development at an early stage: Cornerstones and pedagogical approaches for teacher professional development. Sustainability 2019, 11, 719. [CrossRef]

49. Liarakou, G.; Kostelou, E.; Gavrilakis, C. Environmental volunteers: Factors influencing their involvement in environmental action. Environ. Educ. Res. 2011, 17, 651-673. [CrossRef]

50. Norðdahl, K.; Jóhannesson, I.Á. 'Let's go outside': Icelandic teachers' views of using the outdoors. Education 2014, 44, 3-13, 391-406. [CrossRef]

51. Monroe, M.C.; Ballard, H.L.; Oxarart, A.; Sturtevant, V.E.; Jakes, P.J.; Evans, E.R. Agencies, educators, communities and wildfire: Partnerships to enhance environmental education for youth. Environ. Educ. Res. 2016, 22, 1098-1114. [CrossRef]

52. Aguayo, C.; Eames, C. Promoting community socio-ecological sustainability through technology: A case study from Chile. Int. Rev. Educ. 2017, 63, 871-895. [CrossRef]

53. Simonova, P.; Cincera, J.; Kroufek, R.; Krepelkova, S.; Hadjichambis, A. Active citizens: Evaluation of a community-based education program. Sustainability 2019, 11, 663. [CrossRef]

54. Dillon, J. On learners and learning in environmental education: Missing theories, ignored communities. Environ. Educ. Res. 2003, 9, 215-226. [CrossRef]

55. Crompton, H.; Burke, D.; Gregory, K.H. The use of mobile learning in PK-12 education: A systematic review. Comput. Educ. 2017, 110, 51-63. [CrossRef]

56. Williams, D.R.; Dixon, P.S. Impact of Garden-Based Learning on Academic Outcomes in Schools. Rev. Educ. Res. 2013, 83, 211-235. [CrossRef]

57. Ernst, J.; Blood, N.; Beery, T. Environmental action and student environmental leaders: Exploring the influence of environmental attitudes, locus of control, and sense of personal responsibility. Environ. Educ. Res. 2017, 23, 149-175. [CrossRef]

58. Jensen, B.B. Health knowledge and health education in the democratic health-promoting school. Health Educ. 2000, 100, 146-154. [CrossRef]

59. Hodson, D. Science education as a call to action. Can. J. Sci. Math. Technol. Educ. 2010, 10, 197-206. [CrossRef]

60. Leiserowitz, A.; Kates, R.; Parris, T. Do global attitudes and behaviors support sustainable development? Environment 2005, 47, 23-36.

61. Short, P.C. Responsible environmental action: Its role and status in environmental education and environmental quality. J. Environ. Educ. 2010, 41, 7-21. [CrossRef]

62. Skamp, K.; Boyes, E.; Stanisstreet, M. Beliefs and willingness to act about global warming: Where to focus science pedagogy? Sci. Educ. 2013, 97, 191-217. [CrossRef]

63. Carleton-Hug, A.; Hug, J.W. Challenges and opportunities for evaluating environmental education programs. Eval. Progr. Plan. 2010, 33, 159-164. [CrossRef]

(C) 2020 by the authors. Licensee MDPI, Basel, Switzerland. This article is an open access article distributed under the terms and conditions of the Creative Commons Attribution (CC BY) license (http://creativecommons.org/licenses/by/4.0/). 